Journal of Social Sciences 7 (3): 391-407, 2011

ISSN 1549-3652

(C) 2011 Science Publications

\title{
Faculty Members and Students Perceptions of E-Learning in the English Department: A Project Evaluation
}

\author{
Hamad Al-Dosari \\ Department of English, King Khalid University, Abha, Saudi Arabia
}

\begin{abstract}
Statement of the Problem: With the brisk technology developments, e-learning is revolutionalising the educational industry by leaps and bounds, thus becoming a popular method of education for many universities and colleges around the world. In Saudi Arabian universities, there is a tangible presence of Web-based curricular provisions within the traditional university known as blended learning. There is a growing call advocating the inclusion of online learning in every university to provide distance education. There are many issues that arise problematically. Some of these issues include study overload, lack of technological skills and feelings of isolation, problems in course design and course delivery formats. There are other organizational issues related to accreditation and quality assurance procedures. Approach: This study examines this progressive trend by literature review and survey and whether it is promising for the future of English Language Teaching (ELT) in Saudi Arabia. The study also assesses the effectiveness of and preference for, webbased learning as perceived by faculty and students. Results: Faculty and student responses were generally positive overall and indicated that learning improved in an e-learning environment compared to a traditional approach. Conclusion/Recommendations: The results of this study will inform EFL educators as to whether this mode of learning would serve as viable component of future ELT university programmes in English departments in Saudi universities and guide future research efforts towards more efficient and competitive online learning environments.
\end{abstract}

Key words: E-learning, web-based learning/teaching, ELT, KSA

\section{INTRODUCTION}

Web-based learning, often called online or elearning includes online course content discussion forums via email, videoconferencing and live lectures (video-streaming via synchronous or asynchronous teaching); these possibilities and several others are all available through the web. E-learning is an outcome of an information revolution across all disciplines, including foreign language learning and teaching.

With these brisk developments in information and telecommunication technology applications worldwide, a dire need for developing a national strategy for reforming education and especially English Language Teaching (ELT) in Saudi Arabia has been strongly advocated (Al-Sharhani, 2000). According to the University World News website,

"Saudi Arabia's King Abdullah has called for a national plan to adopt information technology across the country. The plan recommends implementation of e-learning and distance learning and their prospective applications in higher education".

Notes that the Internet penetration rate in Saudi Arabia is $10.6 \%$ (average worldwide $=27.4 \%$ ) and that user growth rate is $1.170 \%$ while the average worldwide is $222.5 \%$. He further describes Saudi Arabia as the 47th country out of 60 major nations with 4.50 points out of 10 which makes it ready to install elearning programmes on a wide scale. Therefore, there grew an increasing interest in online learning in higher education fuelled by both the innovations in internetrelated technologies and the desire for flexibility and convenience on the part of both students and instructors in Saudi Arabia.

The need for this flexibility and convenience in the delivery of university education and other instructional/training courses across all levels of education has been identified by various initiatives in Arabia aiming at maintaining widening participation in education in all sections and across all ages in the Saudi society as well as sustaining professional development. Of such initiatives is the SBM-KIT partnership for course delivery in the master's program on the Internet for Saudi students interested to pursue their master's degrees in business administration or in science, as well as the STC initiatives for enhancing e-learning opportunities in Saudi Arabia in collaboration with the Ministry of Higher Education. With the widespread use of technology and technology literacy, there has been a 


\section{J. Social Sci., 7 (3): 391-407, 2011}

notable increase of interest and activity within computerized learning technologies over the past decade, specifically online learning made possible by the development of the Internet. Further and above all, Web-based education-the now most popular form of distance education-can be provided synchronously and asynchronously, thereby catering to a wide variety of needs, given the availability of computers and the internet and the interactive nature of most online learning today. In point of fact, contemporary distance learning can be seen as a product of 30 years of research and implementation of computerized learning technologies (Chumley-Jones et al., 2002).

Distance learning technologies are a response to a number of challenges in contemporary education, including rising costs, reduced operating budgets and overused personnel and physical resources as well as changes in life styles of people, especially the working class who aspire to continue their education (Goldstein and Ford, 2002).

In Saudi Arabia, policy-makers, educational researchers, educators and the general public and particularly students are gaining awareness of the advantages of these technologies and are adopting them widely, though yet in some limited form. For example, Saudi universities are establishing e-learning centers and e-learning communities and some very limited courses are compulsorily delivered asynchronously online in the form of blended learning.

In fact, there is currently a growing interest in blended learning in Higher Education worldwide as indicated by the growing number of effectiveness research in this area (Irons et al., 2002; Stubbs and Martin, 2003; O'Toole and Absalom, 2003; MacDonald and McAteer, 2003). In university education, there arises 'the need for an holistic approach to embedding e-learning in institutional activities'. Blended learning arises when students are taught via 'a combination of face-to-face and online media' (Voos, 2003). This has come into being after the Saudi Ministry of Higher Education had established the National Centre of Elearning and Distance Learning, known as the ELC, to organize the change and prepare e-learning material. Nine universities have already agreed to implement the system in attempts to transfer to an e-learning system integrated with the traditional system of education. For instance, students in King Khalid University where this study was conducted, are encouraged to take online courses, not as a second-class alternative, but as a firstclass method of instruction. This is not discrepant from many parts of the world which are in infancy for integrating e-learning with traditional learning in higher education institutions. Usually, online learning configurations range from the integration of web-based technologies and conventional lecture courses, to the development of innovative online courses conducted entirely via distance learning (Lebel et al., 2005).

The merits of e-learning, as a culmination of distance education all along the past three decades and as the most popular open education facilities currently, have now been established in research findings across all disciplines (Gilmore and Warren, 2007; Oh, 2003; Bernard et al., 2004; Crutsinger et al., 2005; Stokes et al., 2004; Tallent-Runnels et al., 2006; Poole, 2006; Tham and Werner, 2005; Newsome, 2008). Nevertheless, there are many issues that affect their successful completion of online courses. Some of these issues include work overload, lack of technological skills and feelings of isolation (Newsome, 2008).

Many institutions are not prepared for the challenges involved in offering quality online learning; especially, there is a lack of a reliable assessment tool for evaluating and improving online courses. Moskal et al. (2006) pointed out that "The expansion of online environment presents formidable challenges to higher education. Universities must confront the demand for new pedagogies, enhanced support for both faculty and students, organizational redefinition, authentic and contextual assessment techniques" (p.27).

Moreover, Willging and Johnson (2004) reported in their survey results tapping into technology-related reasons behind e-learning that a "lack of technical preparation for the programme" contributed to a high drop-out rate (p.115). It becomes evident, as Lynch (2001) emphasized that "effective student and faculty preparation for the Web-based teaching and learning environment can make a significant impact on student success in their studies, thus increasing retention and curriculum completion" (p.3).

In light of this tremendous growth, it is critical to examine various important factors that must be considered in order to create effective online courses. These factors include the need to increase online student completion rates, provide training to online instructors, support students' technological skills and develop more valid and reliable online evaluation methods. The investigation of these elements guided the researcher's investigation into the intricacies of developing a high quality online education. Therefore, there is a need to build on the accumulated expertise associated with conventional teaching in order to establish best practices for effective online learning and instructions and to devise appropriate pedagogical, organizational and technological paradigms that will shape the groundwork for future courses (Lebel et al., 2005; Harasim et al., 1995). 


\section{J. Social Sci., 7 (3): 391-407, 2011}

The purpose of the current study was to contribute to the body of literature on behaviorally oriented webbased instruction by assessing the efficiency of and preference for two supplemental learning modules within an online course in order to determine, empirically, the viability of these commonly used learning tools. In other words, the present study evaluates the effectiveness of and preference for webbased learning as perceived by faculty and students in the English department based on their perceptions of how effective e-learning is or have been for them as derived from a questionnaire study.

Nature and problem of the study: The focus of the present study was to recognize the perceptions of faculty and students as to the e-learning endeavor at King Khalid University by probing the opinion of a sample of undergraduate students and their teachers enrolled in the English Department, College of Language and Translation, Abha. Two courses (Drama and Novel) were studied in both the traditional delivery method of classroom attendance for one semester and the e-learning online delivery method in the second semester in the academic year (2008-2009).

Because it may seem easier to augment an already busy schedule with an internet course, rather than a traditional face-to-face course, some students may take on more study than they can handle. There is reason to believe students enrolled in traditional courses are busier than those enrolled in traditional classes. In addition to their enrollment in an online course, they may be involved in the following: (a) a full- or parttime job; (b) face-to-face classes; or (c) extracurricular activities, such as athletics, on-campus or off-campus activities, or any other study. As the study piles up, students might drop the online courses in order to catch up. In addition, if the students feel that the online instructor is not qualified to teach the class, then they will probably drop out or their performance in the final test which is usually given in traditional assessment format incompatible with the online delivery method may be negatively affected. Therefore, the problem of the present study was established in the following research questions:

- What are the perceptions of faculty and students of the online undergraduate courses in the English department in terms of the effectiveness of the elearning medium

- Is there a significant difference between the students and the instructors in their perceptions of the online courses
- What constitutes an effective online course based on instructor perspectives, student perspectives and researcher observations

Review of related literature: In the past two decades, there has been tremendous growth in the availability and feasibility of college and university courses taught partially or entirely online. University education is evolving by leaps and bounds to online learning, where students learn in invisible or virtual classrooms. With the advancement of technology and the Internet, the world has become a vast storehouse of information and learning is no longer limited by distance, location, or physical existence. One of the defining characteristics of online education is that it allows students access to learning without the constraints of time and location (Morrison et al., 2004). Unquestionably, there is an online learning boom occurring and this form of educational delivery has become a top priority for the 21 st century higher education system (Bagnato, 2004).

Institutions of higher education have embraced the Internet as an important vehicle for delivering courses and programs to a wide array of audiences. In the past decade, higher education has gone from a few schools offering online programs to the point where $63 \%$ of all institutions of higher learning were offering undergraduate courses online in 2005 and $65 \%$ were offering graduate courses (Sloan, 2004). Over the next decade, the growth of online students is expected to average around 40\% per year (Dolezalek, 2003; 2004).

In online learning environments, the educator acts as a consultant who maintains close monitoring, but does not interfere with student efforts to address the problems at hand. Students are expected to act with initiative and enthusiasm, reason effectively and creatively with an integrated, flexible, usable knowledge base and monitor and assess their own abilities to achieve desirable outcomes. Research over several decades has found strong evidence for the effectiveness of distance learning (Moore and Thompson, 1997).

According to Tham and Werner (2005), online learning effectiveness is the intersection of three factors or aspects of the learning process: Technology, students and institution. An online learning environment has to emphasize these three factors shown in Fig. 1. The researchers based on a thorough review of literature have concluded that "ineffectiveness in any (of these) factors will have an adverse effect on the successful conduct of learning" (Tham and Werner, 2005). 


\section{J. Social Sci., 7 (3): 391-407, 2011}

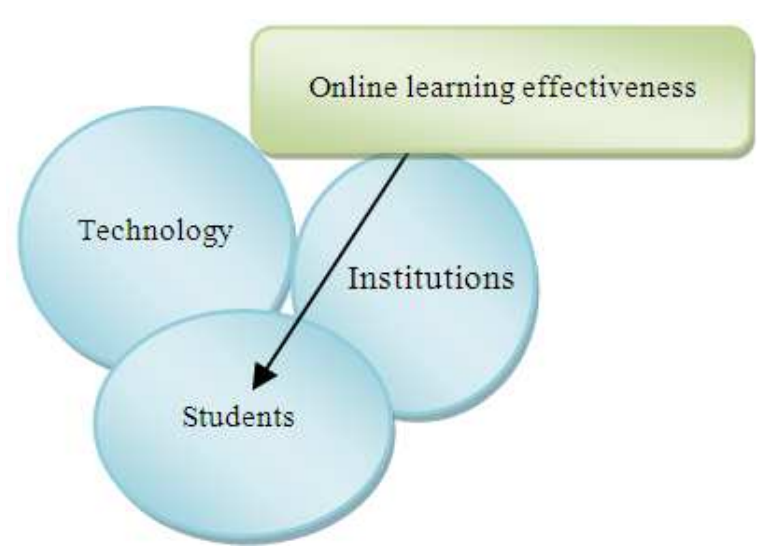

Fig. 1: Factors influencing the effectiveness of online learning (Tham and Werner, 2005)

Therefore, making the best of these factors is a great challenge for institutions conducting online learning projects. As for students and their learning, pertinent literature reports two key approaches to facilitate online learning that have a basis in accepted learning theory. These have been identified by Starr and are described as directed instruction and studentcentered approaches (Starr, 1998). Directed instruction is the achievement of learning by the provision of teacher-directed systematic instruction and this is what is described as the provision of information. Research on online learning and student factors indicated a correlation between the delivery method and such factors as learning styles, motivation and attitudes thought to be enhanced in an e-learning environment (Poole, 2006; Mekheimer, 2005; Crutsinger et al., 2005; Moller, 1998; Daniel, 1996).

Institutional factors are determined by the availability of the infrastructure necessary for conducting e-learning as well as the readiness of faculty and staff to accommodate to e-learning demands and requirements. Researchers noted that online learning using synchronous and asynchronous computer-based instruction is on the increase institutionally in the United States and Britain as in many regions around the world (Tallent-Runnels et al., 2006; Tham and Werner, 2006).

As for technology, the third factor in e-learning, or Internet-Based Instruction (IBI), or Web-Based Learning (WBL) and so on with the names, the essential factor is the Internet. According to Wegner et al. (1999), the practice of using technology to deliver coursework in higher education 'has seen a veritable explosion'. The use of technology has not only created new opportunities within the traditional classroom, but has also served to expand learning experiences beyond the popular notion of "classroom" as an interesting, attractive and indulgently interactive media of learning and/or teaching. Furthermore, utilization of the Internet in what's called 'distance learning, or Internet-based learning or e-learning' is becoming a widely used delivery alternative at universities worldwide. In this context, Wegner et al. (1999) write: "In many instances, the change to an Internet-based delivery system has been instituted with little or no consideration of the impact on student learning". However, makes the following observations.

"Because of the popularity of the Internet and, by extension, the World Wide Web, e-learning has taken a detour from its roots in correspondence courses and teleconferencing. The breadth of this detour would have been hard to predict when Web-based courses began to appear in 1993 in the United States and in other parts of the world. With this population in mind, the growth in demand for Internet distance learning courses is not surprising. Such courses meet the requirements of these students, allowing them to complete degrees begun years before or to take courses to enhance their employment or improve their skills."

One key issue in e-learning is communication between participants, for which there are two basic types of technological solutions: Asynchronous and synchronous (Warschauer, 1996). In the asynchronous approach, the interaction between parties does not require them to be engaged at the same point in time. In synchronous communications the interaction between participants requires simultaneous engagement of the participants. Examples of technologies for asynchronous communications are hypertext publication (namely www), e-mail, mailing lists, newsgroups/bulletin boards and file download (ftp). For synchronous communications the more often used technologies are: chat/IRC, whiteboard, audio-video streaming and videoconference. These new instructional media are being empirically tested for classroom applications and some more web-based learning models are being proposed for instructional effectiveness.

Pedagogically, studies have shown that e-learning can significantly increase the return on investment for training. Technology-based training or e-learning, therefore, can save time without decaying learning benefits (Fletcher; 1999). In a 1990 review of over 40 different studies in industry, education and the military, Fletcher (1990) found that across all studies, approximately $31 \%$ savings in time was achieved when multimedia training was compared to equivalent classroom instruction. Many of the studies he reviewed demonstrated over $35 \%$ savings in time. 
Adams (1992) reviewed six "controlled" studies that directly compared traditional classroom instruction to equivalent multimedia instruction at Xerox, IBM, Federal Express and other companies. He found "learning compression" rates of 38-70\%. Union Pacific experienced 35 and 50\% reductions in learning time for two critical courses delivered to several hundred employees (Cantwell, 1993). Kulik found that across several years and hundreds of studies in education over $30 \%$ reductions in instructional time were achieved.

Hall's in-depth review (personal contacts with over 100 companies involved with multimedia training, meta-analysis of over 30 other studies and several detailed case studies, 1995a, 1995b) found that "there is very strong evidence that computer-based training requires less time for training compared to instructorled training," and that "the amount of reduction ranges from $20-80 \%$, with $40-60 \%$ being the most common. The research evidence indicates that e-learning has the following advantages:

- Minimizes travel costs

- Minimizes time away from study. (Fletcher, 1990)

- Is more cost effective

- Meets the needs of a geographically disperse employees. (Adams, 1992)

- $\quad$ Provides consistent course delivery. (Adams, 1992)

- Offers more individualized instruction. (Adams, 1992)

- Produces consistently higher learning results than traditional training. (Fletcher, 1990; Adams, 1992)

Recent research reveals that over $85 \%$ of lecturers believe e-learning improves teaching creativity and student learning success (Willging and Johnson, 2004). Online learning has the potential to bring new opportunities to higher education. More and more students are now studying part-time, or are unable to attend every lecture because of conflicting demands on their time. It is no longer sufficient to offer only faceto-face teaching and assessment and without online facilities, the problems of student retention and decreasing success rates would be exacerbated.

Research also found that $83 \%$ of lecturers have received positive feedback from their students in response to introducing online teaching and learning (Willging and Johnson, 2004).

\section{MATERIALS AND METHODS}

The field study: Evaluation research was deemed useful for assessing the quality of some aspects of the current programs of study, where the researcher explores the effectiveness of these different aspects of educational curriculum, such as instructional methods, strategies and materials. This genre of research can provide a basis for decisions that are significant in the evaluation of current educational practices (Patton, 2002).

Methods of data collection: The survey instruments consisted of the Instructor Reflection Survey (originally developed by (Filimban (2008)) and Arabicised and standardized by the researcher) and the Student Reflection Survey (originally developed by Newsome, 2008, adapted, Arabicised and standardized for purposes of the present study by the researcher). Both survey forms included close-ended Likert scale statements (quantitative data) and open-ended questions (qualitative data). These instruments were used to measure the factors that contributed to the effectiveness of online courses from instructor and student perspectives.

Sample and tools: The Instructor Reflection Survey was given to twenty teachers in the Faculty of Languages and Translation, English Department, who were involved in blended teaching to English Department students at the time of research or before they joined the department. All sampled teachers responded to the questionnaire. The Online Instructor Reflection Survey gathered descriptive data from the instructors in order to look for correlations between teaching experience and course effectiveness. Instructors were asked about their teaching experience, course development experience and faculty ranking. The questionnaire sought both quantitative and qualitative data.

The student reflection survey was given to 212 full time students. It gathered descriptive data from students both to provide background information on the respondents' online courses they were currently enrolled in and their levels and aspects of satisfaction with the online courses in terms of professionalism, the program content and material, supplementary modules, their recommendations for improving the content of this course and recommendations for improving the appearance of the online program. The first two questions on this survey were Likert-scale type and the remaining two sought for qualitative responses. 
Table 1: Instructors' ranks

\begin{tabular}{lcr}
\hline Faculty rank & No. & $(\%)$ \\
\hline Assistant Professor & 6 & 30 \\
Lecturer & 6 & 30 \\
Instructor & 8 & 40 \\
Total & 20 & 100 \\
\hline
\end{tabular}

Table 2: Online courses taught by the sample

\begin{tabular}{lll}
\hline Online courses taught & Frequency & $(\%)$ \\
\hline Drama (ENG 332) & 10 & 50 \\
Novel (431) & 10 & 50 \\
\hline
\end{tabular}

Table 3: Overall teaching experience at KKU

\begin{tabular}{lcr}
\hline Overall teaching experience at KKU & No. & $(\%)$ \\
\hline Less than one year & - & - \\
1 year to less than 2 years & 3 & 15 \\
2 years to less than 3 years & 9 & 45 \\
3 years to less than 5 years & 2 & 10 \\
5 years to less than 10 years & 6 & 30 \\
Total & 20 & 100 \\
\hline
\end{tabular}

Table 4: Teaching experience in higher education institutions

\begin{tabular}{lcc}
\hline Previous teaching experience & No. & $(\%)$ \\
\hline Yes & 14 & 70 \\
No, if no skip question \#5 & 6 & 30 \\
Total & 20 & 100 \\
\hline
\end{tabular}

Validity of the instruments: Inter-rater validation indicated the instruments were valid enough to collect the data they were meant to gather.

Reliability: The reliability of the questionnaire has been determined using the Kuder-Richardson formula (21) (Brown, 1996; 1997). The reliability co-efficient computed for the 30 items was 0.76 , which is a fairly high.

The survey was administered to (12) faculty members and junior staff members to determine its reliability, manipulating a test-retest method. The reliability of the survey was determined using the Kuder-Richardson formula (21). The reliability coefficient computed for the survey items was 0.81 .

\section{Findings:}

Instructors' reflection surveys: The instructors' reflection survey gathered descriptive data from the instructors in order to look for correlations between teaching experience and course effectiveness. Instructors were asked about their faculty rank, teaching experience and course development experience. They were also asked how long they had been teaching at $\mathrm{KKU}$ and how long they had been teaching the ecourses under investigation in this research. The results of the questions on the survey indicated instructors' teaching experience. The results are summarized in Table (1-7).

The Fig. 2 summarizes these percentages.

The Fig. 3 summarizes these percentages
Table 5: Total of teaching experience in higher education institutions Total number of teaching years in higher education institutions

Less than one year

1 year to less than 2 years

2 years to less than 3 years

3 years to less than 5 years

5 years to less than 10 years

10 years to less than 20 years

Total

\begin{tabular}{rc} 
No. & $(\%)$ \\
\hline- & - \\
6 & 42.9 \\
2 & 14.3 \\
3 & 21.4 \\
3 & 21.4 \\
- & - \\
14 & \\
\hline
\end{tabular}

Table 6: Overall online course development experience

\begin{tabular}{lrr}
\hline $\begin{array}{l}\text { Overall online course } \\
\text { development experience }\end{array}$ & No. & $(\%)$ \\
\hline 1 course & 2 & 10 \\
$2-3$ courses & 5 & 25 \\
$4-5$ courses & 9 & 45 \\
6 or more courses & 4 & 20 \\
Total & 20 & 100 \\
\hline
\end{tabular}

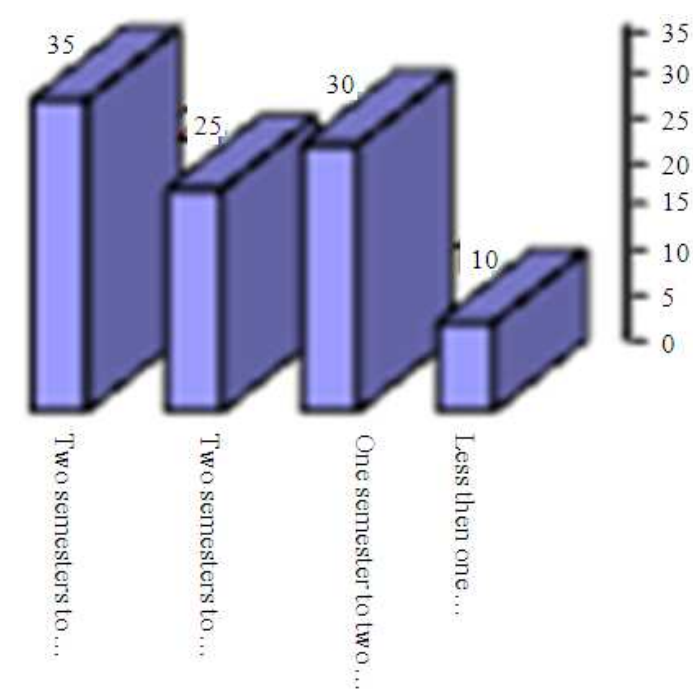

Fig. 2: Experience with online teaching

Figure 2 indicates that instructors who have taught less than one semester scored $(10 \%)$ which is less in having correlations between teaching experience and course effectiveness. It can be due to less number of years of experience. Those who taught one semesters scored (30\%) which means there is a very good correlation between working experience and achievement. The score shows that the instructors are quite expert in elearning However, for those who taught two semesters and above, the percentage varies. Some of them scored $(25 \%)$ which is good as they have less experiencing terms than those who scored (35\%) which is the excellent percentage that links between experience and course effectiveness.

Figure 3 illustrates that those who taught one course scored (10\%) as compared to those who taught 2-3 courses and scored (25\%). 


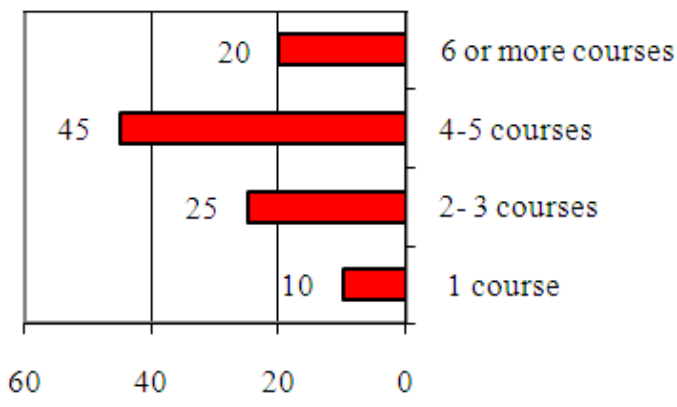

Fig. 3: Online course development

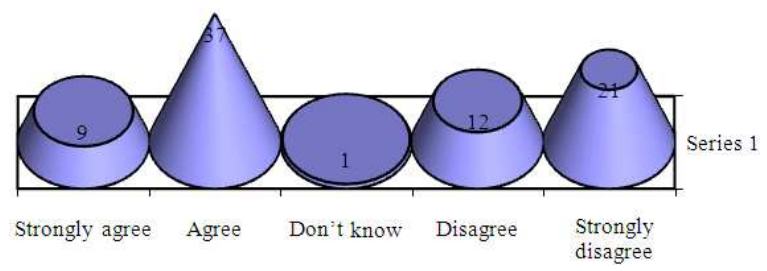

Fig. 4: Instructional design and delivery of online courses

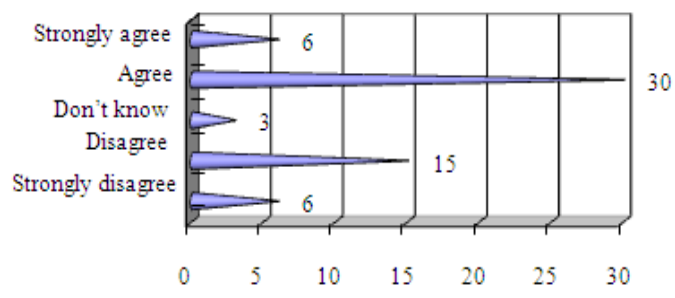

Fig. 5: Student learning outcomes

The latter figure has an average percentage as compared to the former one which is weak. An interesting value is shown by those who taught $4-5$ courses; they score (45\%) which shows that there is an excellent link between the working experience and the achievement. The more number of courses shows the less percentage scored as in (20\%) which shows less interest in teaching done by instructors.

The ranks of faculty informants included assistant professors, lecturers and language instructors, indicating that the greater percentage, astonishingly, went for instructors.

Figure 4 indicates that those who agree that the items in Table 7 are okay scored (37\%) as compared to those who strongly agree as they score (9\%). Those who do not know about them score (1\%). However, those who disagree that the items are not suitable score $(12 \%)$ as compared to those who strongly disagree as they score $(21 \%)$.
The first question in this survey requested information about the ranks of the faculty involved in teaching the online course selected for this study. The results show that $30 \%$ of faculty were assistant professors, $30 \%$ lecturers, $40 \%$ language instructors. The most startling result about the online courses taught by the instructing participants was that $60 \%$ of faculty members were involved in teaching English literature courses while $40 \%$ of the faculty was involved in teaching English language courses. None of the instructors who participated in this research were teaching for the first time, although 10\% said they taught the courses for less than one semester while 35\% taught these courses for about four semesters. At the other end of the spectrum, none of the instructors had been teaching the courses involved in the study for over 10 years; yet, $15 \%$ were teaching for $1-2$ years and $30 \%$ were teaching for 5-10 years. Thus, for the most part, the instructors who participated in this research study have had some teaching experience at KKU. Interestingly, $70 \%$ of the instructing participants had previous teaching experience of teaching in higher education institutions. Of this 70 and $42.9 \%$ have had one to two years teaching experience, while none had more than 10 years experience.

Table 7 above provided information about the instructors' experience in designing online courses. Course development experience data demonstrated that many of the instructors involved in this research had developed 4-5 online courses. Only 10\% developed only one online course, $25 \%$ developed from one to three online courses while $20 \%$ designed more than six courses for online teaching. This low percentage of online instructors with low experience in online course delivery could be attributed to the fact that the KKU policy does not allow low experienced teachers to deliver courses online. As for the responses of faculty regarding their agreement to the organization of instructional design and online course delivery, table 8 summarizes these responses.

In a successful online class, instructional design and delivery provide students with clearly stated expectations and strategies for meeting these expectations, as well as plenty of regular, useful feedback and opportunities for collaboration. The software used in delivering online courses in KKU is the Blackboard Academic Suite technology.

According to informants' responses, $65 \%$ of the faculty agreed that the course structure and materials are well organized while $35 \%$ disagreed to this. Further, $80 \%$ of the informants disagreed to the statement that the online syllabus lacks coherence and interconnectedness. On the other hand, 5\% were neutral and $10 \%$ agreed to the statement. 
Table 7: Instructional design and delivery of online courses

\begin{tabular}{|c|c|c|c|c|c|c|c|c|c|c|}
\hline \multirow[b]{3}{*}{ Items } & \multicolumn{10}{|c|}{ A. instructional design and delivery } \\
\hline & \multicolumn{2}{|c|}{ Strongly disagree } & \multicolumn{2}{|c|}{ Disagree } & \multicolumn{2}{|c|}{ Don't know } & \multicolumn{2}{|c|}{ Agree } & \multicolumn{2}{|c|}{ Strongly agree } \\
\hline & No. & (\%) & No. & (\%) & No. & (\%) & No. & (\%) & No. & (\%) \\
\hline The course structure and materials are well organized. & 2 & 10 & 5 & 25 & - & - & 10 & 50 & 3 & 15 \\
\hline The syllabus lacks coherence and interconnectedness. & 16 & 80 & 1 & 5 & 1 & 5 & 1 & 5 & 1 & 5 \\
\hline $\begin{array}{l}\text { The course is designed with various visual, textual, and/or } \\
\text { auditory activities that improve the students' learning. }\end{array}$ & - & - & 1 & 5 & - & - & 18 & 90 & 1 & 5 \\
\hline The course content is appropriate and up-to-date & 3 & 15 & 5 & 25 & - & - & 8 & 40 & 4 & 20 \\
\hline
\end{tabular}

Table 8: Student learning outcomes

\begin{tabular}{|c|c|c|c|c|c|c|c|c|c|c|}
\hline \multirow[b]{3}{*}{ Items } & \multicolumn{10}{|c|}{ B. Student learning outcomes: } \\
\hline & \multicolumn{2}{|c|}{ Strongly disagree } & \multicolumn{2}{|c|}{ Disagree } & \multicolumn{2}{|c|}{ Don’t know } & \multicolumn{2}{|c|}{ Agree } & \multicolumn{2}{|c|}{ Strongly agree } \\
\hline & No. & $(\%)$ & No. & $(\%)$ & No. & $(\%)$ & No. & $(\%)$ & No. & (\%) \\
\hline $\begin{array}{l}\text { Learning outcomes are clearly explained. } \\
\text {. }\end{array}$ & 1 & 5 & 4 & 20 & 1 & 5 & 11 & 55 & 3 & 15 \\
\hline Tasks are clearly defined. & - & - & 5 & 25 & - & - & 14 & 70 & 1 & 5 \\
\hline Sufficient time for achieving outcomes. & 5 & 25 & 6 & 30 & 2 & 10 & 5 & 25 & 2 & 10 \\
\hline
\end{tabular}

Table 9: Assessment and evaluation

\begin{tabular}{|c|c|c|c|c|c|c|c|c|c|c|}
\hline \multirow[b]{3}{*}{ Items } & \multicolumn{10}{|c|}{ B. Student learning outcomes: } \\
\hline & \multicolumn{2}{|c|}{ Strongly disagree } & \multicolumn{2}{|c|}{ Disagree } & \multicolumn{2}{|c|}{ Don't know } & \multicolumn{2}{|c|}{ Agree } & \multicolumn{2}{|c|}{ Strongly agree } \\
\hline & No. & $(\%)$ & No. & $(\%)$ & No. & $(\%)$ & No. & $(\%)$ & No. & $(\%)$ \\
\hline 1. Assessments are haphazard & 11 & 55 & 6 & 30 & 2 & 10 & 1 & 5 & - & - \\
\hline 2. How students will be graded in the class is clearly explained & 6 & 30 & 5 & 25 & - & - & 7 & 35 & 2 & 10 \\
\hline 3. Assignments with appropriate levels of difficulty are provided & 8 & 40 & 5 & 25 & - & - & 3 & 15 & 3 & 15 \\
\hline 4. Feedback on assignments is provided within a reasonable timeframe & 4 & 20 & 3 & 15 & 1 & 5 & 8 & 40 & 4 & 20 \\
\hline
\end{tabular}

Table 10: Student empowerment

\begin{tabular}{|c|c|c|c|c|c|c|c|c|c|c|}
\hline \multirow[b]{3}{*}{ Items } & \multicolumn{10}{|c|}{ D. Student empowerment } \\
\hline & \multicolumn{2}{|c|}{ Strongly disagree } & \multicolumn{2}{|c|}{ Disagree } & \multicolumn{2}{|c|}{ Don't know } & \multicolumn{2}{|c|}{ Agree } & \multicolumn{2}{|c|}{ Strongly agree } \\
\hline & No. & (\%) & No. & $(\%)$ & No. & (\%) & No. & (\%) & No. & (\%) \\
\hline The students are given opportunities to express themselves & 2 & 10 & 4 & 20 & - & - & 7 & 35 & 7 & 35 \\
\hline The students are given opportunities to share their cultural backgrounds & 6 & 30 & 5 & 25 & 1 & 5 & 6 & 30 & 2 & 10 \\
\hline The students are given a voice in how they will be graded & 5 & 25 & 7 & 35 & 1 & 5 & 6 & 30 & 1 & 5 \\
\hline
\end{tabular}

Table 11: Social presence

\begin{tabular}{|c|c|c|c|c|c|c|c|c|c|c|}
\hline \multirow[b]{3}{*}{ Items } & \multicolumn{10}{|c|}{ E. Social presence } \\
\hline & \multicolumn{2}{|c|}{ Strongly disagree } & \multicolumn{2}{|c|}{ Disagree } & \multicolumn{2}{|c|}{ Don’t know } & \multicolumn{2}{|c|}{ Agree } & \multicolumn{2}{|c|}{ Strongly agree } \\
\hline & No. & $(\%)$ & No. & $(\%)$ & No. & $(\%)$ & No. & $(\%)$ & No. & $(\%)$ \\
\hline Students are encouraged to post a self-introduction on white board & 3 & 15 & 4 & 20 & 1 & 5 & 7 & 35 & 5 & 25 \\
\hline Students are required to think in-depth about a subject & 1 & 5 & 1 & 5 & 3 & 15 & 7 & 35 & 8 & 40 \\
\hline Anonymity can lead to cheating and other unethical practices & 9 & 45 & 6 & 30 & - & - & 4 & 20 & 1 & 5 \\
\hline Students are given opportunities for positive interactions with other students & 7 & 35 & 6 & 30 & 1 & 5 & 4 & 20 & 2 & 10 \\
\hline Students are helped to feel part of a learning community & 6 & 30 & 4 & 20 & 2 & 10 & 5 & 25 & 3 & 15 \\
\hline
\end{tabular}

In general, this section tapped into the respondents' views concerning organization and design of the online courses, agreement to whose statements (57.5\%) indicated that the courses were well-designed and finely organized and integrated with the purposes and activities of learning, as is shown in the above Fig. 4.

Table 10 contains data about the students' empowerment. Item one gives opportunities to students to express themselves, item two give opportunities to students to use their cultural background and item three gives a chance to the students to argue about the grades.

Table 11 talks about the social presence and there are five items. Item one gives a chance to the students to introduce themselves on a white board, item two indicates that students are supposed to think deeply about the given subject, item three includes information about anonymity in questions which will lead to cheat and students may do unethical practices, item four talks about positive interactions between students and item five shows that students are helped to feel a part of a learning community Fig. 5 indicates that those who agree that the items in Table 8 are suitable scored (30\%) as compared to those who strongly agree with the same items as they scored (6\%). 
Table 12: Study and thinking skills

\begin{tabular}{|c|c|c|c|c|c|c|c|c|c|c|}
\hline \multirow[b]{3}{*}{ Items } & \multicolumn{10}{|c|}{ F. Study and thinking skills } \\
\hline & \multicolumn{2}{|c|}{ Strongly disagree } & \multicolumn{2}{|c|}{ Disagree } & \multicolumn{2}{|c|}{ Don't know } & \multicolumn{2}{|c|}{ Agree } & \multicolumn{2}{|c|}{ Strongly agree } \\
\hline & No. & $(\%)$ & No. & $(\%)$ & No. & $(\%)$ & No. & $(\%)$ & No. & (\%) \\
\hline Students are required to think in-depth about a subject & 3 & 15 & 4 & 20 & 2 & 10 & 9 & 45 & 2 & 10 \\
\hline Students are required to analyze, synthesize, and interpret information & 2 & 10 & 5 & 25 & 1 & 5 & 8 & 40 & 4 & 20 \\
\hline Students are required to problem solve & 2 & 10 & 1 & 5 & 1 & 5 & 5 & 40 & 5 & 40 \\
\hline Courses can help students develop critical and creative thinking & 3 & 15 & - & - & - & - & 6 & 45 & 5 & 40 \\
\hline
\end{tabular}

Table 13: Course alignment

\begin{tabular}{|c|c|c|c|c|c|c|c|c|c|c|}
\hline \multirow[b]{3}{*}{ Items } & \multicolumn{10}{|c|}{ G. Course alignment } \\
\hline & \multicolumn{2}{|c|}{ Strongly disagree } & \multicolumn{2}{|c|}{ Disagree } & \multicolumn{2}{|c|}{ Don't know } & \multicolumn{2}{|c|}{ Agree } & \multicolumn{2}{|c|}{ Strongly agree } \\
\hline & No. & $(\%)$ & No. & (\%) & No. & (\%) & No. & (\%) & No. & (\%) \\
\hline Assignments that reflect student interests and abilities are provided & 1 & 5 & 2 & 10 & 1 & 5 & 9 & 45 & 7 & 35 \\
\hline Learning outcomes are in alignment with the course requirements & 2 & 10 & 1 & 5 & 3 & 15 & 8 & 40 & 6 & 30 \\
\hline $\begin{array}{l}\text { Course assessments are in agreement with the course } \\
\text { content and learning objectives }\end{array}$ & 2 & 10 & 3 & 15 & - & - & 8 & 40 & 7 & 35 \\
\hline
\end{tabular}

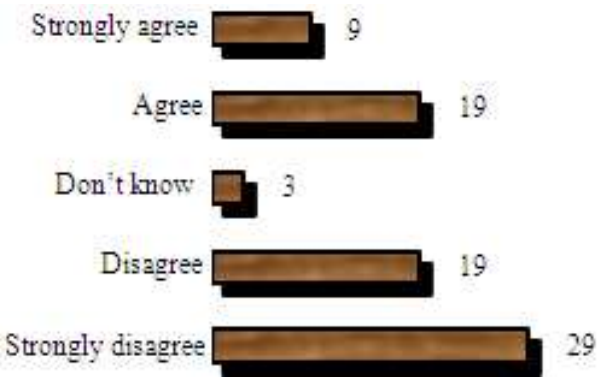

Fig. 6: Assessment and evaluation

Those who do not know about them scored (3\%) However, those who disagree that the items are not suitable scored $(15 \%)$ as compared to those who strongly disagree as they scored (6\%).

Figure 6 indicates that those who agree that the items in Table 9 are acceptable scored (19\%) as compared to those who strongly agree as they scored (9\%). Those who do not know about them scored (3\%). While, those who disagree that the items are not suitable scored (19\%) as compared to those who strongly disagree as they scored (29\%).

Informants have also reported on how they perceived student learning outcomes in e-learning contexts. Out of total responses, $70 \%$ of the informants amongst faculty noted that the learning outcomes outlined in the syllabus are clearly explained. Also, $75 \%$ indicated that the tasks that are required to successfully complete the class are clearly defined. 55\% of faculty disagreed that sufficient time is allowed for achieving outcomes, while $35 \%$ agreed to this statement. Perhaps the reason for this is that a lot of the learning effort is done on the part of the students in asynchronous e-learning environment or on their own at their home which is the essential feature of e-learning. Overall, informants indicated better learning outcomes of the e-courses; this is shown in the above Fig. 5.

As for assessment and evaluation, informants indicated that assessments are not done haphazardly (85\% disagreed to the statement that assessments are haphazard) while $10 \%$ were neutral. Also, participants were split into two halves, one half believing that grading systems are clearly explained in class, while the other half disagreed. Further, $60 \%$ indicated that feedback on assignment is provided within a reasonable time-frame, expectedly because of the Blackboard software used. The Fig. 6 above generally shows much disagreement as to the efficiency of online assessment procedures. The reason could be that the overlap in evaluative procedures as well as the variety of assessments techniques utilized in e-learning environments could lead some teachers and students as well to be confused. Table 12 is about the study and thinking skills; it has four items. Item one indicates that students are required to think in-depth about a subject. Items two specifies that students are required to analyze, synthesize and interpret information. Item three indicates that students are required to problem solve and item four improves that courses can help students develop critical and creative thinking.

Table 13 talks about course alignment in which item one shows the assignments that reflect student interests and abilities that are provided, item two illustrates the learning outcomes are in alignment with the course requirements and item three shows the course assessments which are in agreement with the course content and learning objectives. 


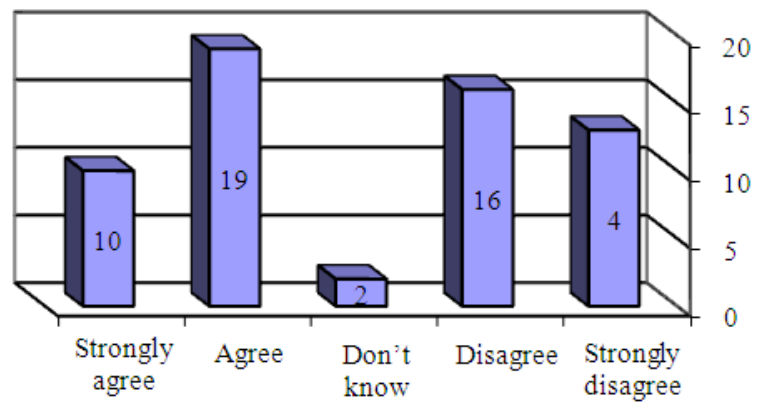

Fig. 7: Student empowerment

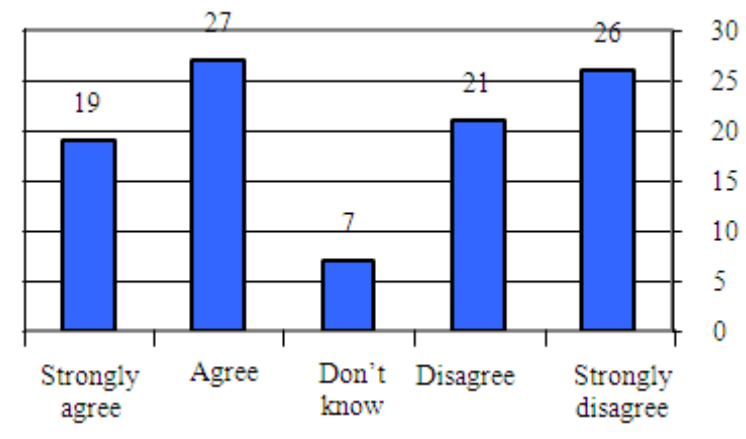

Fig. 8: Social presence

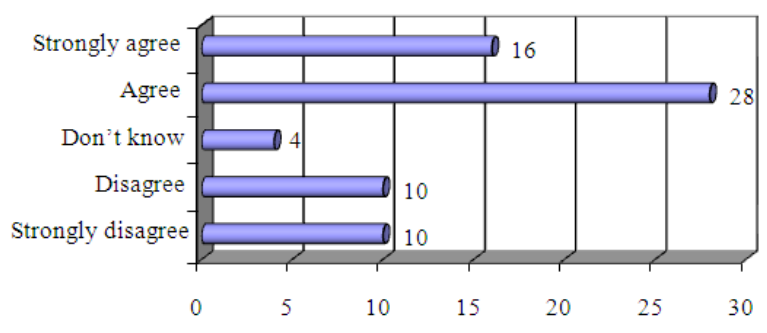

Fig. 9: Study skills

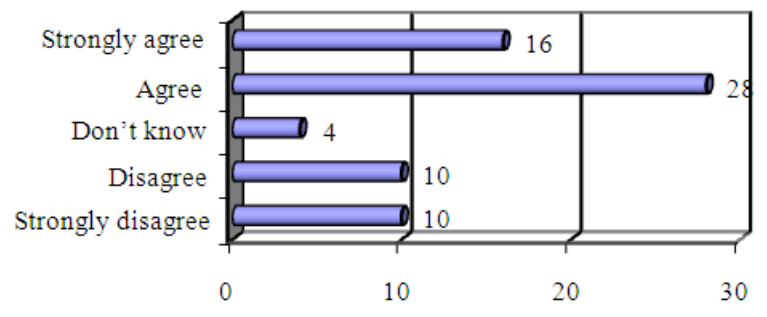

Fig. 10: Study and thinking skills

Figure 7 shows that those who agree that the items in Table 10 are good enough scored (19\%) as compared to those who strongly agree as they scored (10\%). Those who do not know about them scored $(2 \%)$. However, those who disagree that the items are not suitable score $(16 \%)$ as compared to those who strongly disagree as they scored $(4 \%)$.There is also the problem of how to transfer the evaluation results into the credit hours system. Furthermore, some assessments occur in a haphazard fashion in online environments.

Most participants (70\%) indicated that students are given opportunities to express themselves in online courses more than it is the case in traditional course delivery methods. By the same token, 55\% disagreed to the statement that students are given opportunities to share their cultural backgrounds.

In the same vein, $70 \%$ also disagreed as to giving students the opportunity to express their views as to how they would be graded. Maybe the regulations of the KKU are rigid here and no dictum can even be considered as regards the university grading system which is unbreakable even by faculty. The Fig. 7 shows general concurrence to the overall statements in Table 10.

The Fig. 8 below shows general concurrence to the overall statements in Table 11.

Figure 8 indicates that those who agree that the items in Table 11 are sufficient scored $(27 \%)$ as compared to those who strongly agree as they scored (19\%). Those who do not know about them scored (7\%). However, those who disagree that the items are not suitable score $(21 \%)$ as compared to those who strongly disagree as they scored (26\%).

A great percentage of informants (70\%) agreed that they encourages their students to post a selfintroduction on white board. $75 \%$ of the informants disagreed to the statement indicating that students can interact positively in the e-learning environment with their peers; this could be perhaps due to the nature of the virtual learning environment itself which constrains peer interactions. Therefore, half the informants disagreed to the point that students in this virtual learning environment felt they were part of a larger learning community. $75 \%$ also agreed that online courses require deep thinking, while $15 \%$ were neutral and $10 \%$ disagreed. However, a greater percentage $(55 \%)$ agreed that specific subject area in-depth thinking was required as part of the online course. About $60 \%$ also concurred that online course delivery induces the development of higher order thinking skills such as analysis, synthesis and interpretation, which are core skills to creative thinking.

Figure 9 indicates that those who agree that the items in Table 12 are met scored (29\%) as compared to those who strongly agree as they score (16\%). Those who do not know about them scored (4\%). However, those who disagree that the items are not suitable score $(10 \%)$ as compared to those who strongly disagree as they scored (10\%). 
Table 14: Benefits of online courses

\begin{tabular}{lcl}
\hline Benefits of online courses & Frequency & $(\%)$ \\
\hline Accessibility & 14 & 70 \\
Flexibility & 9 & 45 \\
Student centered & 11 & 55 \\
Encourages collaboration & 7 & 35 \\
\hline
\end{tabular}

Table 15: Benefits of online courses

\begin{tabular}{lcc}
\hline Drawbacks of online courses & Frequency & $(\%)$ \\
\hline Isolation & 16 & 80 \\
Lack of face-to-face interactions & 16 & 80 \\
Time intensive & 6 & 30 \\
Lack of technological skills & 10 & 50 \\
for student and/or faculty & &
\end{tabular}

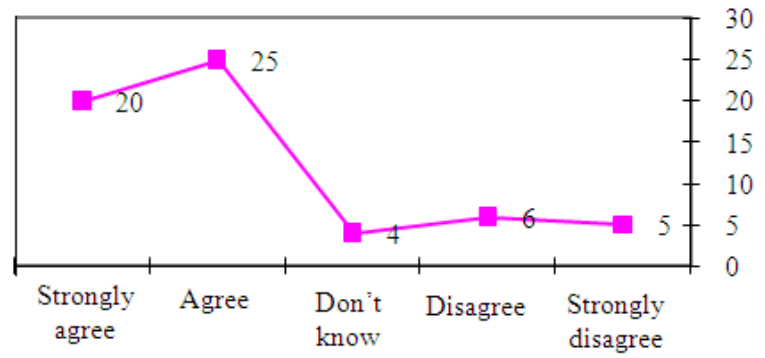

Fig. 11: Course alignment

Figure 10 indicates that those who agree that the items in Table 12 are useful scored (28\%) as compared to those who strongly agree as they scored (16\%). Those who do not know about them scored (4\%). However, those who disagree that the items are not suitable score (10\%) as compared to those who strongly disagree as they scored (10\%).

Figure 11 indicates that those who agree that the items in Table 13 are convincing scored $(25 \%)$ as compared to those who strongly agree as they scored (20\%). Those who do not know about them scored (4\%). However, those who disagree that the items are not suitable score $(6 \%)$ as compared to those who strongly disagree as they scored $(5 \%)$.

The Fig. 10 above shows this comparison. As for course alignment, more teachers said that assignments reflected student interests and abilities provided (80\%), while $45 \%$ agreed they did. As well, $70 \%$ agreed that learning outcomes are in alignment with the course requirements. A similar percentage $(75 \%)$ concurred that assessments are in agreement with the course content and learning objectives. Overall, about $45 \%$ of the responses range between Agree and Strongly Agree to the statements of Table 13 tapping into the alignment of the course as is shown in Fig. 11.

The Table 14 illustrates the benefits of online courses insofar as accessibility, flexibility, student centered and encourages collaboration are concerned.
Table 15 shows drawbacks of online courses with regard to isolation, lack of face-to-face interactions, time intensiveness and Lack of technological skills for student and/or faculty. As well, 80\% and $85 \%$ agreed that online courses help in developing problem solving skills and critical and creative thinking skills, respectively. A great percentage also (75\%) disagreed that anonymity is conducive to cheating and other unethical practices, while $25 \%$ agreed to this point. Overall agreement to statements of Table 12 refers to a wider concurrence to the statements, which indicates that online course delivery could be inducing to more creativity and critical thinking of the students inasmuch as instructors believed.

Benefits of online course delivery: The Table 14 summarizes the responses of the informants as to their views on the benefits of online course delivery. In their views, accessibility is the greatest benefit of online courses $(70 \%)$ and then comes student centeredness (55\%) and flexibility (45\%) and finally collaboration $(35 \%)$.

Informants in the open-ended part of the question tapping into their views about other benefits indicated that online courses provide increased opportunities for learning and alternative formats for information, enhances student-to-student and faculty-to-student communication, enables a variety of methods to assess and evaluate student progress. Informants also mentioned other benefits such as time flexibility and geographic flexibility. Others indicated that students don't have to attend classes or take notes. Another benefit mentioned is the fact that students who tend to be shy about participating in a physical classroom are usually much more conversational in an online classroom. They tend to be more willing to post comments on the class discussion forum and are usually more prone to ask their instructor a question via email. As a consequence, a shy or timid individual can have a more positive learning experience in the online environment.

Drawbacks of online courses: The Table 15 summarizes the responses of the informants as to their views on drawbacks of online courses: Informants agreed with higher percentages up to $80 \%$ that isolation and lack of face-to-face interactions are the major drawbacks of online course delivery. Then, they mentioned that technical skills of faculty or students could be another major drawback (50\%). 


\section{J. Social Sci., 7 (3): 391-407, 2011}

In the open-ended responses, they mentioned other disadvantages such as discipline-related problems and time management problems, difficulties with credit transfer, difficulties with access to knowledge and technology. Some informants, in this vein, noted that online courses is more time consuming than teaching traditional courses because communication via email or discussion boards requires more time than communication conducted during a face-to-face class. Another disadvantage of online courses mentioned by faculty is the complete lack of supervision.

Effects on teaching pedagogy: A great number of informants $(95 \%)$ responded that online course delivery has affected their teaching methods and styles. Most of them have recognized the importance of developing sound pedagogy that meets the needs of all students. As with other types of pedagogy, however, the effectiveness of online teaching depends upon the way instructors utilize the available resources. According to respondents, online course instruction may become the preferred instructional delivery method for some students and for themselves as well if the full range of content, goals of the course and methods and styles of presentation are amenable to technology and the outcomes are equal to those of traditional methods. So they can deliver online course content through a variety of instructional tools including media presentations and notes, computerized tutorials, links to outside resources, discussion forums and e-mail for communication among students and the instructor include the way in which online courses can be accommodating to many teaching and learning styles, but given technological impediments, it is difficult to accommodate everyone. Furthermore, there is a problem with time management in online course design and online teaching; informants indicated that online teaching can be more timeconsuming, as it requires daily interaction. Specifically, instructors emphasized that they spent more time helping some students to understand the materials.

Many participants indicated that the effective online class provided a variety of supporting media as earlier said, such as discussion forums and e-mail for communication. As such, they highly appreciated the broader integration of materials that are embedded in online course delivery, such as video clips, web links and audio lectures. Another interesting dichotomy of perspective was the way in which students tended to view the instructor as the most important element to providing a successful learning environment, while the teachers tended to view the course structure, objectives and communication mediums as the most important.

Effects on traditional teaching: Regarding question 12 on the teachers' survey, it was noted that online teaching which uses technology and web resources can also impact traditional course design. Informants suggested that their online teaching experience had also impacted the way in which they teach their on-campus courses. They find that the availability of online resources, the unique nature of online communication and the extensive use of written communication have all caused them to re-evaluate their teaching in the traditional classroom. Several instructors stated that they now incorporate more web resources, web-based assignments and online multimedia technologies in the traditional classes.

Effects on assessments and evaluation techniques:

The diversity of assignments and activities helps address the need for variety in student learning. Informants, with greater frequency of responses in several wordings, noted that assessments could be improved through course evaluations and peer assessment, though some teachers expressed that these were not always as effective in an online environment as on campus. They were uncertain of ways to improve these methods and expressed concerns. The blackboard technology, it was said by some informants, can be used to buttress effective evaluation methods used to review student study, such as monitoring assignments, blackboard discussions, projects and quizzes.

Critical components of effective online courses: Informants indicated that there are certain components which are critical to the success of online courses, such as instructor availability, clear directions, interaction and communication, a dynamic curriculum and technical accessibility all contribute both to learning and the ease of use in an online course. Others referred to more interesting and livelier materials, thought-provoking questions and a variety of quizzes and exercises will generate motivation and enthusiasm for learning. But more significantly, informants made frequent mentions about the grading system; they indicated that course materials, instructions and grading systems must be "organized, well written and up-to-date," while assignment deadlines should be "frequent and firm".

Improvement of online courses at KKU: Faculty suggestions: Informants in greater frequency of responses indicated that more systematic faculty training as to how to use blackboard e-learning technology. 


\begin{tabular}{|c|c|c|c|c|c|c|c|c|c|c|}
\hline \multirow[b]{3}{*}{ Items } & \multicolumn{10}{|c|}{ A. professionalism } \\
\hline & \multicolumn{2}{|c|}{ Strongly agree } & \multicolumn{2}{|c|}{ Agree } & \multicolumn{2}{|c|}{ Neutral } & \multicolumn{2}{|c|}{ Disagree } & \multicolumn{2}{|c|}{ Strongly disagree } \\
\hline & No. & (\%) & No. & $(\%)$ & No. & (\%) & No. & (\%) & No. & $(\%)$ \\
\hline 1. The instructor is on time for all appointments & 62 & 34.4 & 54 & 30.0 & 25 & 13.9 & 23 & 12.8 & 16 & 8.9 \\
\hline 2. The instructor is helpful and courteous & 24 & 13.3 & 32 & 17.8 & 18 & 10.0 & 49 & 27.2 & 57 & 31.7 \\
\hline 3. The instructor responds to email in a timely manner & 71 & 39.4 & 44 & 24.4 & 38 & 21.1 & 8 & 4.4 & 19 & 10.6 \\
\hline 4. I find the instructor's explanations of the content interesting & 59 & 32.8 & 61 & 33.9 & 40 & 22.2 & 7 & 3.9 & 13 & 7.2 \\
\hline
\end{tabular}

Table 17: Online Programme

\begin{tabular}{|c|c|c|c|c|c|c|c|c|c|c|}
\hline \multirow[b]{3}{*}{ Items } & \multicolumn{10}{|c|}{ B. online programme } \\
\hline & \multicolumn{2}{|c|}{ Strongly agree } & \multicolumn{2}{|c|}{ Agree } & \multicolumn{2}{|c|}{ Neutral } & \multicolumn{2}{|c|}{ Disagree } & \multicolumn{2}{|c|}{ Strongly disagree } \\
\hline & No & $(\%)$ & No & $(\%)$ & No & $(\%)$ & No & $(\%)$ & No & $(\%)$ \\
\hline 1. The online programme runs smoothly & 57 & 31.7 & 51 & 28.3 & 37 & 20.6 & 21 & 11.7 & 14 & 7.8 \\
\hline 2. I had plenty of experience with computers before taking this class & 23 & 12.8 & 28 & 15.6 & 31 & 17.2 & 52 & 28.9 & 46 & 25.6 \\
\hline $\begin{array}{l}\text { 3. I find the online programme more convenient than meeting } \\
\text { as a class on a monthly basis }\end{array}$ & 54 & 30.0 & 49 & 27.2 & 42 & 23.3 & 30 & 16.7 & 5 & 2.8 \\
\hline 4. The appearance of the online program is attractive and easy to read & 48 & 26.7 & 40 & 22.2 & 39 & 21.7 & 42 & 23.3 & 11 & 6.1 \\
\hline $\begin{array}{l}\text { 5. I feel like I am mastering the material and will be able to } \\
\text { apply what I am learning in the future }\end{array}$ & 46 & 25.6 & 50 & 27.8 & 29 & 16.1 & 31 & 17.2 & 24 & 13.3 \\
\hline
\end{tabular}

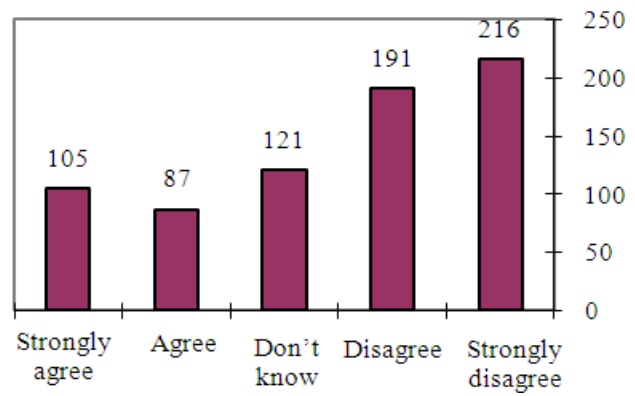

Fig.12: Professionalism

They also requested that technicians should always be readily available to help solve the problem Table 16 includes information about professionalism which has four items; item one talks about the instructor's full time job for the appointments, item two indicates that the instructor is helpful and courteous, item three mentions the instructor's responses to email in a timely manner and item three includes the instructor's explanations of the content interesting.

Table 17 contains information about Online Programme which has five items: item one shows the smooth way that the program runs, item two shows the instructor's experience with computers before taking this class, item three shows that the online program is more convenient than meeting, item four expresses the appearance of the online program as attractive and easy to read and item five talks about mastering of the material which will be apply to learning in the future

Figure 12 indicates that those who agree that the items in Table 16 are suitable scored $(87 \%)$ as compared to those who strongly agree as they scored (105\%). Those who do not know about them scored ( $121 \%)$. However, those who disagree that the items are not suitable score (191\%) as compared to those who strongly disagree as they scored $(216 \%)$.

Figure 13 indicates that those instructors who agree that the items in Table 17 are good scored $(20 \%)$ as compared to those who strongly agree as they scored (11\%). Those who do not know about them scored (20\%). However, those who disagree that the items are not suitable score (24\%) as compared to those who strongly disagree as they scored (25\%). That crop up sometimes with the Blackboard program. Many informants indicated that the program does not sometimes function well outside the campus when they try to access the system from servers other than the KKU's server. Some also mentioned that it is sometimes difficult to upload outside web information, like visual and audio content. Furthermore, they expressed a desire for more interaction and the development of a community of online professors. Some many requested more collegial professional development and coordination to make best use of Blackboard.

Thoughts about online course delivery in KKU: In a nutshell, informants expressed a liking to teach online because it suits their teaching styles, they like the community of learners who tend to chose online courses and they enjoy the relaxed learning atmosphere.

Nevertheless, some divulged several negative aspects of online teaching, such as time management, physical and social presence of faculty; a great many are hired from other Arab countries and those expressed a feeling of disturbance as to potential firing in case online course delivery would become the norm, or at least, they would be doing the job online at their own places abroad. Those also believe that "personal, faceto-face interaction between student and professor and between student and student is optimal". 


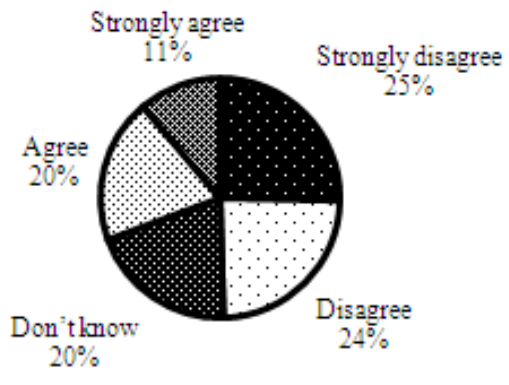

Fig. 13: Online programme

Results from the students' reflection survey: The students' reflection survey requested evaluative information on professionalism, the online program, other online supplementary material, as well as openended suggestions and recommendations to ameliorate online teaching and learning. Table 16-17 depict the average numeric scores for each survey question across all participants on the Students' Reflection Survey with regard to professionalism and the online program respectively. In general, there was a high degree of student satisfaction with faculty professionalism, but far less satisfaction with the online program as is demonstrated in Fig. 12-13, with virtually all aspects of the course about which the survey inquired into. Descriptive data indicated that $40 \%$ of student informants were enrolled in Drama courses (ENG 332) and the remaining $60 \%$ were enrolled in Novel (ENG 431). Table 16 below summarizes responses on professionalism. It shows that $84 \%$ agreed that instructors in synchronous online course delivery were available on time according to the schedule. Astonishingly, $31.1 \%$ responded that instructors of online courses were helpful and courteous, while 58.9\% disagreed that they could be as such. This could be attributed to the anonymous nature of online teaching. However, as professionally expected, $63.8 \%$ replied that online teachers responded to email communications efficiently; this could be attributed to the nature of online teaching and the Blackboard e-learning suite used which requires posting of notes and emailing in appropriate protocols. What is also interesting, though, was that $66.7 \%$ informed that the online instructors' explanations of the content were interesting. This could be due to the fact that multi-modal presentations of lessons were provided, given that multimedia presentations, chatting and online note posting, . Were used and available via Blackboard. Overall, disagreement to the statements of Table 17 tapping into the professionalism of faculty teaching the designated courses online overrides their agreement as is shown in Fig. 13. As for their responses to the online courses, the Table 17 summarizes these findings. Of all responses, $60 \%$ agreed that the online program ran smoothly, while $20.6 \%$ were neutral and $19.5 \%$ disagreed to this point. Further, a few of the informants also noted that they had plenty of experience with computers before taking this class $(28.4 \%)$ while a greater percentage $(54.5 \%)$ noted that they didn't have this plenteous experience. Further, $57.2 \%$ agreed that the online program was more convenient than meeting as a class on a monthly basis, while $19.5 \%$ did not concur to this point. Additionally, $48.9 \%$ agreed that the appearance of the online program was attractive and easy to read, while $29.4 \%$ disagreed and a greater percentage $(23.3 \%)$ was neutral as to this point. Interestingly, $53.4 \%$ agreed that they could mater the online course material and they were able to proceed with online learning in the future.

Open-ended questions inquired into the informants' recommendations for improving the content and appearance of online courses. Sorrowfully, students were careless enough to provide comparable data. However, a few responded to the questions indicating that to improve content, they should be investigated as to their learning needs before the syllabus of the course would be designed. They also requested a variety of teaching styles and techniques in online teaching, including online video-based material, PowerPoint presentations and other media material together with text and graphics. Other students indicated that the course material should be developed in the format of an e-book downloadable as pdf to be referred to when necessary.

\section{RESULTS}

The Kingdom of Saudi Arabia is taking strident steps in the field of e-learning by leaps and bounds, either in public education or private education, including university education. The need for e-learning is urgent, given demographic facts that $60 \%$ of the overall population fall in the age category of less than 15 years. This means that those children and early adolescents need to be inducted into the technology of today which will be the basis of future development. Statistics as well indicate that the e-learning market in Saudi Arabia will grow 33\% much as it is now within the coming five years.

Despite this fact that e-learning is growing by leaps and bounds, there are still other problems with technology adoption in Saudi university institutions in order to accommodate to the needs of a 24 million Saudi population. Prevalent amongst these problems, a category of problems related to teachers who lack the training and expertise with e-learning software, as is shown in this study and in other studies suggested in the research review. As demonstrated in other researches, workloads of teachers as well as time management problems constrain the diffusion of e-learning in Saudi universities. Other problems have to do with 
technological glitches related to apparatus and working with technology. Other problems have to do with online course description. Some of these courses in the University Curriculum Regulations are not compatible with the design and requirements of e-courses which need to be updated at least on an annual basis. Other problems have to do with technical infrastructure, online classroom management and the riddles of online evaluation procedures. These problems have been somehow addressed in the present study.

As is shown in this study and other related research in Arabia, qualifications and experience significantly affect the deployment and acceptance of technologybased instruction. With less than 10 years experience, there is more likelihood that faculty may prefer to use technology in their teaching. This is attributable to the fact that they have less work load and hence, they have more opportunities to develop themselves professionally through training in e-learning which is provided systematically by the university. As well, young faculty are more interested in technology much more than old-aged professors who are liable to conducting their courses in traditional formats.

This study also showed that e-courses need to be systematically and regularly updated in terms of organization, appearance and content; some of the present e-courses are formatted in the traditional way, but are only delivered online, just like putting old wine into new bottles. Assessment and evaluation procedures should also be developed to accommodate to the online environment.

No matter how the findings are confusing, it is interesting to note that faculty and student responses indicated that learning overall could improve in elearning conditions much better than in traditional fashions. Even the problems could be points of merit if well managed like time and virtual classroom management problems. For example, presenting both modes of e-learning-synchronous and asynchronous elearning-could is accommodating to all time constraints on the part of students and faculty as well. Further, virtual classroom management problems are far less pressing than real classroom management problems.

\section{REFERENCES}

Adams, G.L., 1992. Why interactive. Interactive Communication http://www.ilearnsystems.com/pdfs/WhyInt4.pdf

Al-Sharhani, J., 2000. Education and the satellite: Possibilities for Saudi Arabia. Int. J. Instruct. Media, 27: 51-57. http://ipac.kacst.edu.sa/eDoc/eBook/2113.pdf
Bagnato, K., 2004. Learning virtually. Commun. College Week. http://imet.csus.edu/classic/classes/280/learn_virtu ally.pdf

Bernard, R.M., P.C. Abrami, Y. Lou, E. Borokhovski and A. Wade et al., 2004. How does distance education compare with classroom instruction. A meta-analysis of the empirical literature. Rev. Educ. Res. Fall, 74: 379-439. DOI: 10.3102/00346543074003379

Brown, J.D., 1996. Testing in Language Programs: A Comprehensive Guide To English Language Assessment. 2nd Edn., Prentice Hal Regents, Upper Saddle River, NJ, 1, pp: 144. ISBN: 0131241575, pp: 324.

Cantwell S., 1993. Multimedia transforms union Pacific's training strategy. Tech. Trends, 38: 21-22. DOI: $10.1007 / \mathrm{BF} 02763783$

Chumley-Jones, H.S., A. Dobbie and C. Alford, 2002. Web-based learning: sound educational method or hype? A review of the evaluation literature. Acad. Med., 77: S86-S93. DOI:10.1097/00001888200210001-00028

PMid:12377715

Crutsinger, C.A., D.K. Knight and T. Kinley, 2005. Learning style preferences: implications for webbased instruction. Cloth Text. Res. J., 23: 266-277. DOI:10.1177/0887302X0502300407

Daniels, J., 1998. Mega Universities and Knowledge Media. 1st Edn., Routledge, London, ISSN: 0749426349, pp: 212.

Dolezalek, H., 2003. Online degrees. Training, 40: 2630.

http://eric.ed.gov/ERICWebPortal/search/detailmin i.jsp?_nfpb=true\&_\&ERICExtSearch_SearchValue _0=EJ665707\&ERICExtSearch_SearchType_0=no \&accno=EJ665707

Dolezalek, H., 2004. The state of the e-learning market. Training, 41: 2028.http://direct.bl.uk/bld/PlaceOrder.do?UIN=1758 87153\&ETOC $=$ RN\&from $=$ searchengine

Filimban, G.Z., 2008. Factors that contribute to the effectiveness of online learning technology at Oregon State University. Oregon State University. http://ir.library.oregonstate.edu/xmlui/handle/195 7/8498

Fletcher, J.D., 1990. Effectiveness and Cost of Interactive Videodisc Instruction in Defense Training and Education. 1st Edn., Institute for Defense Analyses, Alexandria, Va., pp:

Gilmore, S. and S. Warren, 2007. Emotion online: Experiences of teaching in a virtual learning environment. Hum. Relat., 60: 581-608. DOI: $10.1177 / 0018726707078351$ 
Goldstein, I.L. and J. K. Ford, 2002. Training in Organizations. 4th Edn., Wadsworth, Belmont, CA, ISBN: 0534345549, pp: 410.

Harasim, L.M., S.R. Hiltz, L. Teles and M. Turoff, 1995. Learning Networks: A Field Guide to Teaching and Learning Online. 1st Edn., MIT Press, Cambridge, ISBN: 0262082365, pp: 376.

Irons, L.R., R. Keel and C.L. Bielema, 2002. Blended learning and learner satisfaction: Keys to user acceptance. USDLA. J., http://www.usdla.org/html/journal/DEC02_Issue/ar ticle04.html

Lebel, T., E. Olshtain and P.L. Weiss, 2005. Teaching teachers about augmentative and alternative communication: Opportunities and challenges of a web-based course. Augmentative Alternative Commu., 21: 264-277. DOI: 10.1080/07434610500140311

Lynch, M.M., 2001. Effective Student Preparation for Online Learning. The Technology Source Archive. http://www.technologysource.org/article/effective_ student_preparation_for_online_learning/

MacDonald, J. and E. McAteer, 2003. New Approaches to Supporting Students: strategies for blended learning in distance and campus-based environments. J. Educ. Media, 28: 129-146. http://direct.bl.uk/bld/PlaceOrder.do?UIN=143337 $673 \&$ ETOC $=$ RN\&from $=$ searchengine

Mekheimer, M.A.A.G. and B. Soef, 2006. Relationship between students' perceptions of learning environment, learning styles and achievement in an internet-based TEFL methodology course. Qwerty Interdisciplinary J. Technol. Culture Educ. http://www.ckbg.org/qwerty/index.php/qwerty/arti cle/viewArticle/12

Moller, L., 1998. Designing communities of learners for asynchronous distance education. Educ. Technol. Res. Develop., 46: 115-122. DOI: 10.1007/BF02299678

Moore, M.G. and M.M.Thompson, 1997. The Effects of Distance Learning. $1^{\text {st }}$ Edn., American Center for the Study of Distance Education, Pennsylvania State University, University Park, PA, ISBN-10: 1877780189, pp: 112.

Morrison, M., A. Sweeney and T. Heffernan, 2004. Learning styles of on-campus and off-campus marketing students: the challenge for marketing educators. J. Market. Educ., 25: 208-217. DOI: 10.1177/0273475303257520

Moskal, P., C. Dziuban, R. Upchurch, J. Hartman and B. Truman, 2006. Assessing online learning: What one university learned about student success, persistence and satisfaction. peerReview. http://www.highbeam.com/doc/1P31183251081.html
Newsome, W., 2008. An investigation of efficiency and preference of supplemental learning modules in online instruction. The University of Nevada, Reno. http://gradworks.umi.com/14/53/1453604.html

O'Toole, J.M. and D.J. Absalom, 2003. The impact of blended learning on student outcomes: is there room on the horse for two? J. Educ. Media, 28: 179-190. http://direct.bl.uk/bld/PlaceOrder.do?UIN=143337 $708 \&$ ETOC $=$ RN\&from $=$ searchengine

Oh, C.H., 2003. Information Communication Technology and the New University: A view on elearning. ANNALS Am. Acad. Polit. Soc. Sci., 585: 134-153. DOI: 10.1177/0002716202238572

Patton, M.Q., 2002. Qualitative Research and Evaluation Methods. 3rd Edn., Sage Publications, Thousand Oaks, ISBN: 0761919716, pp: 598.

Poole, J., 2006. E-learning and learning styles: students' reactions to web-based language and style at blackpool and The Fylde College. Language Literate., 15: 307-320. DOI: 10.1177/0963947006066129

Qari, A.A., 1999. Training for information technology at king Abdul-Aziz university library. J. Librarianship Infor. Sci., 3: 39-44. DOI: 10.1177/096100069903100105

Allen, I.E., J. Seaman and S. Consortium, 2004. Entering the Mainstream. $1^{\text {st }}$ Edn., Sloan Consortium, Needham, MA., pp: 21.

Starr, D.R., 1998. Virtual education: Current practices and future directions. Int. Higher Educ., 1: 157-65. DOI: 10.1016/S1096-7494(99)80179-2

Stokes, C.W., C. Cannavina and G. Cannavina, 2004. The state of readiness of student health professionals for web-based learning environments. Health Inform. J., 10: 195-204. DOI: 10.1177/1460458204045434

Stubbs, M.A. and I. Martin, 2003. Blended learning: One small step. Manchester Metropolitan University. $\quad$ http://www.e-space.mmu.ac.uk/espace/handle/2173/84304

Tallent-Runnels, M.T., J.A. Thomas, W.Y. Lan, S. Cooper and T.C. Ahern et al., 2006. Teaching courses online: a review of the research. Rev. Educ. Res., 76: 93-135. DOI: $10.3102 / 00346543076001093$

Tham, C. and J. Werner, 2005. Designing and Evaluating E-Learning in Higher Education: A Review and Recommendations. J. Leadership Org. Stud., 11: 15-25. DOI: $10.1177 / 107179190501100203$ 
Voos, R., 2003. Blended learning: What is it and where might it take us. Sloan-C View. http://sloanconsortium.org/publications/view/v2n1/ blended1.htm

Warschauer, M., 1996. Comparing face-to-face and electronic discussion in the second language classroom. Calico J., 13: 7-26. http://www.mendeley.com/research/comparingfacetoface-and-electronic-discussion-in-thesecond-language-classroom-1/
Wegner, S.B., K.C. Holloway and E.M. Garton, 1999. The effects of Internet-based instruction on student learning. JALN, 3: 98-106. http://collections.lib.uwm.edu/cipr/image/401.pdf Willging, P.A. and S.D. Johnson, 2004. Factors that influence students' decision to dropout of online courses. JALN, 8: 105-118. http://sloanconsortium.org/system/files/v8n4_willg ing.pdf 